E. Parmentier $\cdot$ F. Lagardère $\cdot P$. Vandewalle

\title{
Relationships between inner ear and sagitta growth during ontogenesis of three Carapini species, and consequences of life-history events on the otolith microstructure
}

Received: 16 July 2001 / Accepted: 20 March 2002 / Published online: 23 May 2002

(C) Springer-Verlag 2002

\begin{abstract}
Three species of Carapidae have in common a tenuis larval stage, during which they settle in the lagoon and take refuge in the same species of holothuroid. From the juvenile stage, Carapus homei and C. boraborensis are commensal, whereas Encheliophis gracilis is parasitic. The aims of this study were to analyse to what extent the ontogenetic changes of the otic capsule affected the shape of the inner ear and how environmental cues, due to the above-mentioned life history and the style, could influence the structure of the sagitta. Sagittal sections revealed a three-dimensional asymmetry with a nucleus close to the proximal surface. Observations of the growth axis of the sagitta suggest it has a morphogenetic impact on the otic cavity. Each sagitta contains three main zones related to the life stages of the fish. Bands and checks were observed in the third zone in C. homei and C. boraborensis, but this pattern was less discernible in E. gracilis. These structural differences in zone 3 could be related to the commensal and parasitic life styles of these fishes. Further studies dealing with otosac features and otolith functions are suggested.
\end{abstract}

\section{Introduction}

Among the Carapidae (Ophidiiformes), three species belonging to the Carapini tribe, Carapus homei (Richardson,

Communicated by R. Cattaneo-Vietti, Genova

E. Parmentier $(\bowtie) \cdot$ P. Vandewalle

Laboratoire de Morphologie Fonctionelle et Evolutive, Institut de Chimie B6, Université de Liège,

Sart-Tilman, 4000 Liège, Belgium

E-mail: E.Parmentier@ulg.ac.be

Fax: + 32-4-3663715

F. Lagardère

CREMA-L'Houmeau (CNRS-IFREMER),

BP 5, 17137 L'Houmeau, France
1844), C. boraborensis (Kaup, 1856) and Encheliophis gracilis (Bleeker, 1856) have the ability to penetrate and stay inside the respiratory tree and/or the coelomic cavity of various holothurian species (Trott 1970; Jangoux 1974; Parmentier et al. 1998, 2000). C. homei and C. boraborensis are commensal, they feed mainly on benthic invertebrates (annelids, crustaceans) and fish (Smith 1964; Smith and Tyler 1969; Trott 1981; Van Den Spiegel and Jangoux 1989). E. gracilis is parasitic; it only feeds on its host's tissues (Strasburg 1961; Trott 1970). Carapids have a planktonic larval stage called "vexillifer", due to the elongation of the first dorsal-fin ray, the vexillum (Arnold 1956; Olney and Markle 1979) (Fig. 1). This larva transforms into another type of larva, which is called "tenuis", by regressing this vexillum whilst the body lengthens considerably (Padoa 1947). During this stage, the tenuis larva shifts from a pelagic life style to a benthic habitat, to search for its first invertebrate host. It then undergoes a substantial reduction in size at the end of which the juvenile status is reached.

The inner ear of the Carapidae is organised similarly to the pattern common in other teleostean fish. However, the otic area and the stato-acoustic organ exhibit several particularities described in adult fish (Parmentier et al. 2001b). The two most noteworthy concern the location of the pars inferior otolithic end organ (the sacculus and lagena) and the morphology of the sagitta. The whole brain is concentrated at the front of the braincase, and only a thin myelencephalon goes through the otic cavity. Therefore, the nervous axis does not separate the sacculi, making their proximal sides contiguous along the sagittal axis of the fish (otolith orientation and terminology according to Morales-Nin 2000). In the Carapini otolith, a strong dimorphism distinguishes the proximal side from the distal (anti-sulcus) side characterised by a prominence, which contributes to the otolith thickness. This thickening is greater in the parasitic species (E.gracilis) than in the commensal ones (C. boraborensis and $C$. homei). The latter differences could be related to the life style of the fish species (Parmentier et al. 2001b). 


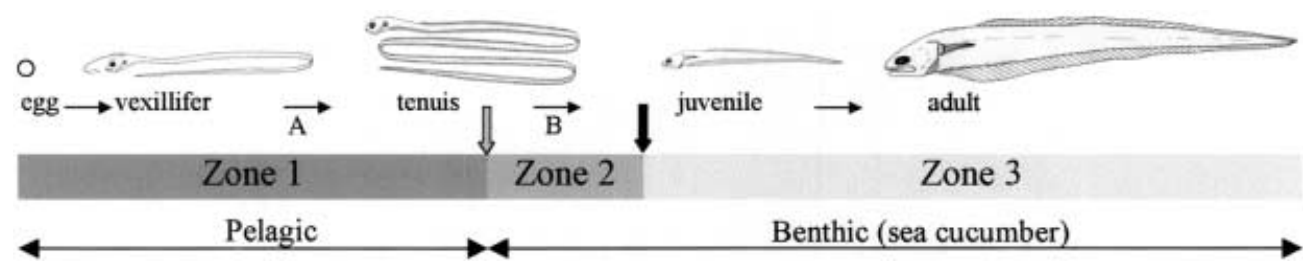

Fig. 1. Schematic representation of the Carapidae life-history stages, with relation to the otolith zones (see "Results" and "Discussion" for further explanations). Pelagic life spans embryo and the larva periods, up to metamorphosis (tenuis stage). A benthic way of life begins once metamorphosis has completed, with transformation of the tenuis into a benthic juvenile

A preliminary examination of these otoliths revealed a pattern common to teleost fish (Degens et al. 1969), with alternately translucent and opaque zones, in which thinner structures were discriminated. Otolith growth depends on endogeneous rhythms that control the deposition of matrix-dominant (D-unit) and mineraldominant (L-unit) layers. This process varies under pressure of ontogenical and environmental events, via fish physiology and metabolism (Campana and Neilson 1985; Gauldie and Nelson 1990; Gauldie et al. 1991; Morales-Nin 2000). Otoliths record significant ontogenetic and ecological events as major discontinuities ("landmarks", Campana and Jones 1992). For example, the habitat shift liable to occur at metamorphosis completion can produce a "settlement" mark within the otolith (Victor 1982, 1986; Wilson and McCormick 1999). In the field, prominent environmental changes lead either to variations in increment width or to other types of discontinuities ("checks"), the formation of which interrupts the regular deposition of increment sequences (Campana and Neilson 1985; Radtke 1987; Morales-Nin 2000). These exogenous factors very often interact, as photoperiod does (Campana 1984; Mugiya 1984) with temperature (Neilson and Geen 1985 Morales-Nin et al. 1995) and food intake (Campana 1983; Zhang and Runham 1992; Moksness et al. 1995; Molony 1996).

This study was initiated as a first step towards ecological studies using the timekeeping properties of Carapini otoliths. It focused on three species, $C$. boraborensis, $C$. homei and E. gracilis, which share certain features. These species have the advantage of living in the same atoll area, at the same depth and in the same holothurian host, Bohadschia argus. In this context, exogenous factors influence body and otolith growth in similar ways in these three species. Otolith variations in shape and structure, if any, should mainly depend on endogenous factors and differences in life strategies.

This study has attempted to clarify the relationships between inner ear development and sagitta formation, from the tenuis to the adult, in order: (1) to discriminate ontogenetic effects from those of life style and (2) to give an ontogenetic or biological explanation for the otolith structures. Two approaches were used to analyse, both in the tenuis larva and in the adult, changes in the otic capsule and the ear, with special emphasis on the sagitta.
The first objective was to define the sagitta position within the otic cavity and the labyrinth, for a better understanding of the mechanisms involved in growth of the otic capsule and otolith. For the second objective, the main ontogenetic patterns due to otolith growth were obtained from sections of tenuis, juvenile and adult otoliths. The resulting set of descriptions is based on the main structural features presented in C. homei cranium, inner ear and otoliths. The description of $C$. boraborensis and E. gracilis has been limited to how it differs from C. homei.

\section{Materials and methods}

Adult specimens of Carapus boraborensis (total length: 13-30 cm), C. homei (TL: 8-17 cm) and Encheliophis gracilis (TL: 16-24 cm) were collected in Opanohu Bay, Moorea, French Polynesia. They were found inside specimens of Bohadschia argus, at depths ranging from 1 to $10 \mathrm{~m}$. Only tenuis larvae and juveniles of $C$. boraborensis and $C$. home $i$ were found in these holothurians. Furthermore, tenuis larvae of $C$. home $i$ were caught at night, while they passed through the coral reef crest, using a net $(1.5 \mathrm{~m}$ wide $\times 0.75 \mathrm{~m}$ high $\times 5 \mathrm{~m}$ long, $1 \mathrm{~mm}$ mesh), which was previously described by Dufour et al. (1996). Tenuis of $C$. boraborensis, $C$. homei and E. gracilis were also caught using the same technique in January and February 1998, off the north coast of Rangiroa Atoll (French Polynesia). All samples were fixed and stored in $70 \%$ ethanol for further analyses.

Stored fish were measured in total length (from the snout to the end of the tail) to the nearest millimetre, without shrinkage correction. All otoliths were extracted using a binocular microscope and cleaned of adherent tissues. Measurements were taken on whole otoliths. The sagittae, lapilli and asterisci were measured along the antero-posterior axis for maximal length, to the nearest $0.01 \mathrm{~mm}$. Optical sections of sagittae were prepared by mounting each otolith on a glass side in thermoplastic cement (Crystal Bond). Double frontal and transverse sections of sagittae were obtained by grinding each side with wet sand paper of decreasing grit sizes (600, 800 and 1200 grit) and polishing them with wet $0.3 \mu \mathrm{m}$ grit paper. Preparations were observed and photographed using a polarised light microscope (Olympus BX50), fitted with an Olympus OM-4 Ti photo camera.

\section{Results}

Otic capsule and inner ear

The body growth and the increase of the sagitta maximal axis length were examined for Carapus homei as related to the neurocranium length (measured from the mesethmoid tip to the basioccipital tip (Fig. 2). Large variations in fish length from the tenuis stage and the juvenile period suggest that the relationship between the fish and otolith size was not simple. Nevertheless, a strong positive linear regression fit the relationship 
Fig. 2. Carapus homei. Relationships of the body (open circle) and of the otolith (black square) lengths, to the head (neurocranium) length (solid line positive linear regression between otolith and neurocranium)

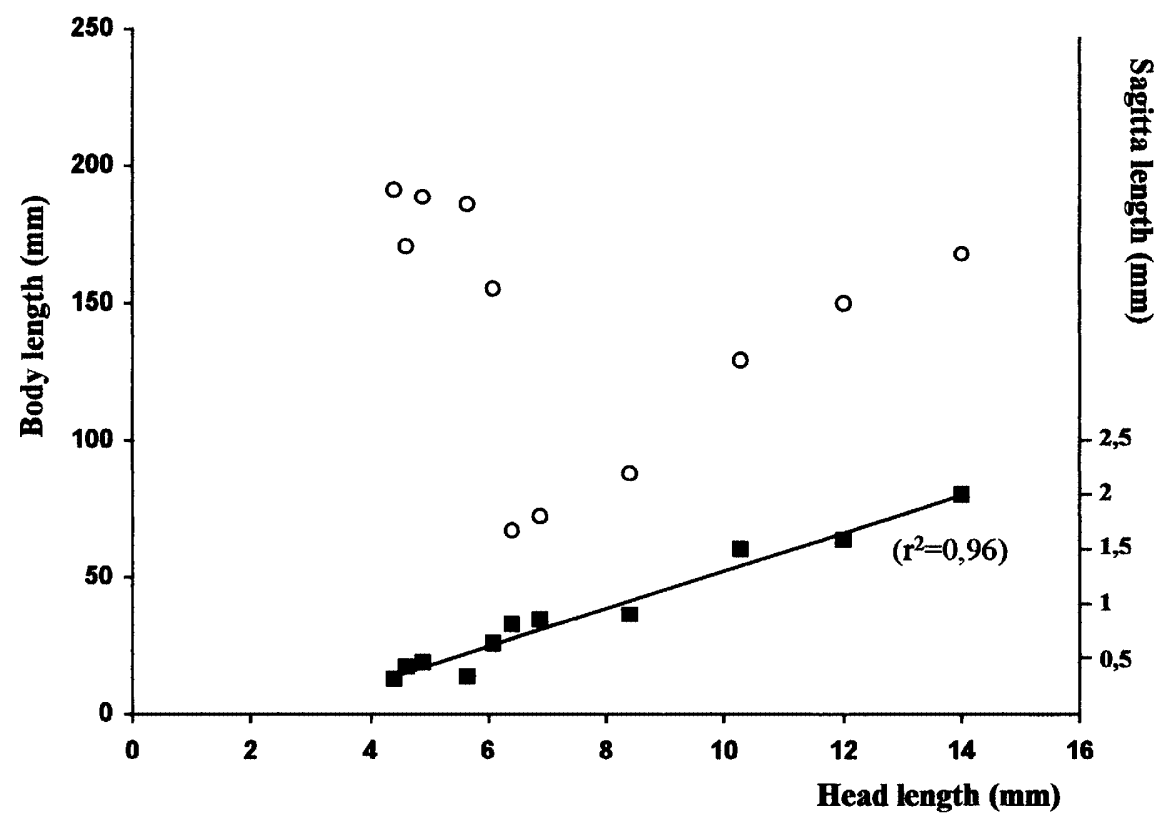

otoliths and post-rostrum differentiation resulted in a substantial increase of the sagitta's size (Fig. 6). the Pearson correlation coefficient $\left(r^{2}=0.96, P<0,0005\right.$, $n=10)$.

However, the morphology of tenuis neurocranium presented some differences compared to the adult neurocranium. In the adult, the anatomy of the otic cavity and inner ear, illustrated for C. homei (Fig. 3), showed the development of the otic capsule (Fig. 3A, B), totally occupied by the inner ear (Fig. 3C), except the thin myelencephalon, which passed in between each of them (Fig. 3D). At the tenuis stage (Fig. 4), the neurocranium differed notably in that: (1) a large space was given to the eye area, whereas the otic cavity was proportionally reduced (Fig. 4A, B); (2) the bony arches, holding the posterior and lateral semi-circular canals in position, were closer than in the adult; (3) the prootic internal wing was situated more ventrally, which gave an anteroventral orientation to the sagitta, compared to the antero-dorsal tilt of the adult otolith (Fig. 4B, C); and (4) only the prosencephalon was not localised in the otic area. Consequently, the right and left inner ears were physically separated by the brain (Fig. 4C, D). As in the adult, the sphenotic contained a plate that sustained the recessus utriculi, and the exoccipital surrounded the asteriscus cavity (Fig. 4). At the tenuis stage, the inner ear organisation was complete, but not its entire differentiation. Compared proportionally to the adult organ (Figs. 3, 4): (1) the sinus superior was narrower and the semi-circular canals were thicker, the anterior and posterior semi-circular canals being higher; (2) differences between the three otolith sizes (lapillus, asteriscus and sagitta) were less prominent (Fig. 5). The post-rostrum had not yet developed in the tenuis sagitta, the shape of which, being roughly circular, appeared thinner than that in the adult otolith. During the juvenile and adult periods, the sagitta increased more than the other two
Sagitta structure in the adult

Sections of frontal and transverse types (Fig. 7) enabled us to cross the nuclear area. The frontal plane was set parallel to the dorsal edge for sectioning both the nucleus and the post-rostrum. Frontal sections showed the coarsely hemi-convex shape of the sagitta (Fig. 8); the proximal side was almost flat, whereas the distal side presented a prominence, the curve of which was broken at the back by development of the post-rostrum. Transverse sections (Fig. 9) revealed two thickenings, which corresponded dorsally to the crista superior, more pronounced than its ventral homologue, the crista inferior. These two crests delimit a slightly convex sulcal groove. On the other hand, the dorsal edge was almost perpendicular to the proximal face, whereas the ventral edge formed a tip (Fig. 9A, B), which was not the case in fish otoliths previously described (Fig. 9C).

Comparisons of these two types of sections in C. homei otoliths emphasised the asymmetrical location of the nucleus (initial accretion centre) within threedimensional space (Figs. 8, 9). The proximo-distal asymmetry came from a central area very close to the sulcus surface, only separated from it by a few very narrow increments. The antero-posterior asymmetry increased from the tenuis stage. Post-rostrum development displaced the otolith's centre toward the anterior edge. The dorso-ventral asymmetry resulted from differential growth, the nucleus being closer to the dorsal edge. The crista superior thus appeared more pronounced than the crista inferior. Sagitta shape results from these growth differences, probably because of 

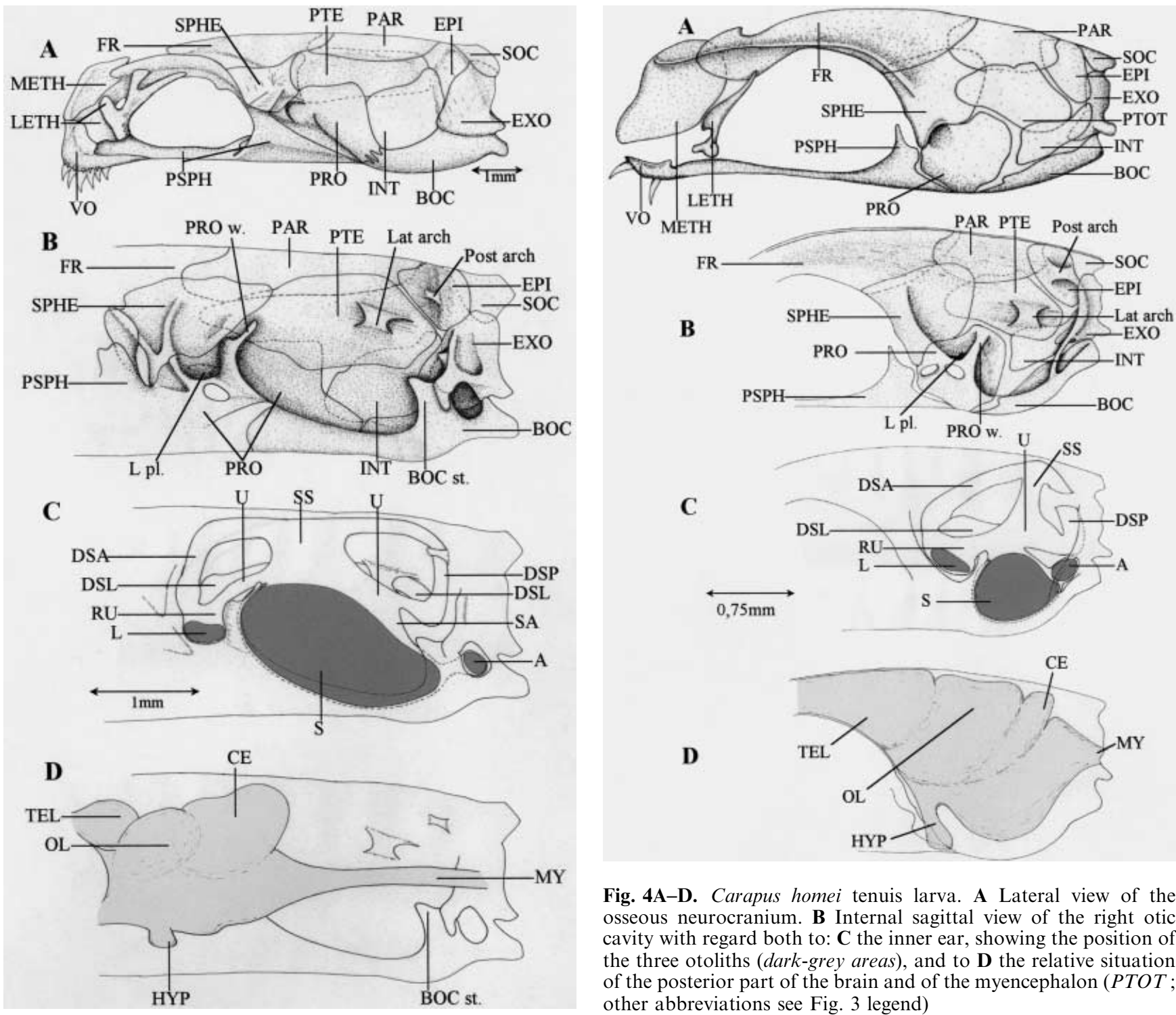

Fig. 3A-D. Carapus homei adult. A Lateral view of the osseous neurocranium. B Internal sagittal view of the right otic cavity with regard both to: $\mathbf{C}$ the inner ear, showing the position of the three otoliths (dark-grey areas), and to $\mathbf{D}$ the relative situation of the posterior part of the brain and of the myencephalon ( $A$ asteriscus; $B O C$ basioccipital; $B O C$ st. basioccipital stem; $C E$ cerebellum; $D S A$ ductus semicircularis anterior; $D S L$ ductus semicircularis lateralis; $D S P$ ductus semicircularis posterior; $E P I$ epiotic; $E X O$ exoccipital; FR frontal; HYP hypophysis; INT intercalarium; $L$ lapillus; $L$. pl. lapillus plate; $L a t$ arch lateral arch; $L E T H$ lateral ethmoid; $M E T H$ mesethmoid; $M Y$ myencephalon; $O L$ optic lobe; Post arch posterior arch; $P A R$ parietal; $P R O$ prootic; $P R O w$. prootic wing; $P S P H$ parasphenoid; $P T E$ pterotic; $R U$ recessus utriculi; $S$ sagitta; $S A$ sacculus; $S P H E$ sphenotic; $S O C$ supraoccipital; $S S$ sinus superior; TEL telencephalon; $U$ utriculus; $V O$ vomer)

relationships between the anatomy of the otic cavity and the posterior, ventral and distal otolith faces. Similar features were observed in C. boraborensis and E. gracilis.

A detailed examination of these sagittal sections showed an internal structure with microincrements made from dark and light units (D- and L-unit, respectively)

and the grouping of these microincrements corresponding to particular otolith areas, an opaque central area followed by opaque and translucent bands (Fig. 8). Although some individual variability appeared in the same species, a common schematic representation emerged in the three species. This diagram was based on three zones constituted of one or several bands. An illustration of these patterns is given for C. homei (Fig. 8) with, in support, comparisons for $C$. boraborensis and E. gracilis (Fig. 10).

1. Zone 1 (Fig. 8A) comprised the nucleus surrounded by an opaque area. Around the nucleus, increments were very thin and not easily discriminated, even at high magnification. From this perinuclear area and reaching the outermost zone 1 area, increments increased progressively in width and definition, due to a higher contrast between the D- and L-units from which they were made. In zone 1, the larval otolith was already elongated along the antero-posterior axis 
Fig. 5A, B. Carapus homei. Lateral views of the sagitta $(S)$ and asteriscus $(A)$ and dorsal view of the lapillus $(L)$ from: $\mathbf{A}$ the tenuis to $\mathbf{B}$ the adult $(A n-D o$ antero-dorsal axes of the sagitta and asteriscus; $A n-D i$ anterodistal axes of the lapillus)
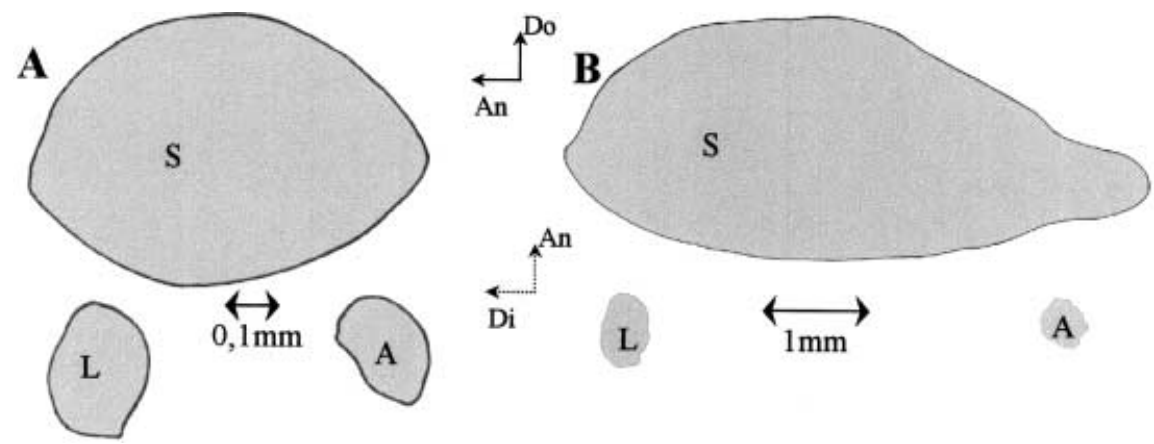

and flattened on the proximal side, compared to the curved distal side. These characteristics resulted in a semi-ellipsoid shape. The mean increment number varied depending on the species: $48( \pm 6.5 ; n=16)$ increments for $C$. boraborensis, $82.7( \pm 4.7 ; n=23)$ for $C$. homei and $68.4( \pm 7 ; n=5)$ for E. gracilis (Parmentier et al. 2001b).

2. Transition to zone 2 was characterised both by an abrupt broadening of each of the increment components that constituted this zone and by changes in their optical properties (Fig. 8A). Although increment width was maximal along the antero-posterior axis, increment definition vanished in zone 2 , at a level which depended on the species. In C. homei sagittae, the D-unit width made opaque the innermost part of this zone, which became progressively translucent (Fig. 8B). In C. boraborensis, zone 2 was narrower and more opaque (Fig. 10A), and a similar pattern was observed in E. gracilis. A single or double ontogenetic "landmark" corresponded to the end of this zone in the three species (post-metamorphic mark, Figs. 8B, C, 10A).

3. The third zone (Fig. 8B, C) comprised increment sequences deposited from this post-metamorphic mark to the otolith margin. It was at this level that the main differences between the three species were noted. In $C$. homei, zone 3 was characterised by groupings of increments in more-or-less regular clusters. Cluster appearance varied, depending on the number and

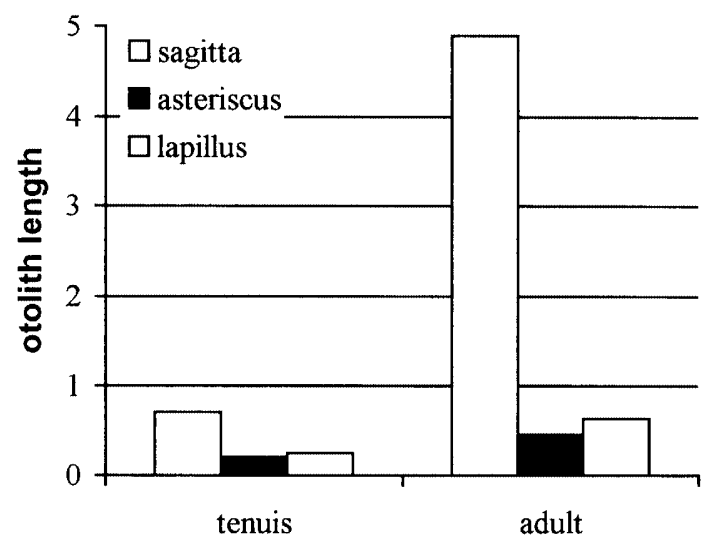

Fig. 6. Carapus homei. Comparisons of changes in relative length $(\mathrm{mm})$ of tenuis and adult otoliths width of the increments they were made from, especially with respect to D-unit thickness. This resulted in translucent and opaque banding patterns of variable width. These bands could, or could not, have been interrupted by checks, the number and distribution of which were also irregular. When checks were present, their deposition came before opaque band formation. They were observed both in the anterior otolith area and at the post-rostrum tip (Fig. 8D). In its innermost area, C. boraborensis zone 3 was similar to the observed patterns in C. homei. However, the post-rostrum area differed in C. boraborensis by showing an increased check number. These checks were distributed in an irregular way within alternately deposited bands, but showing fainter translucent and opaque properties (Fig. 10B). The most striking feature of zone 3 in E. gracilis sagittae came from its component regularity. This concerned both the increment width and the alternating deposition of translucent and opaque bands, being less contrasted and narrower than in the other two species (Fig. 10C). Some checks were also present, except at the otolith margin, but they were less prominent than in the commensal species.

Sagitta structure from the tenuis larva to the juvenile

C. boraborensis and C. homei specimens, caught whilst entering the recifal crest, only presented opaque zone 1 organisation. Tenuis larvae found in the holothurian

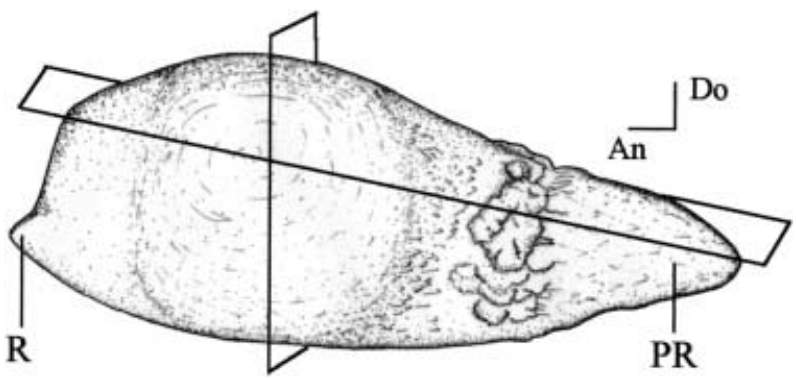

Fig. 7. Carapus boraborensis. Distal view of the sagitta, showing the selected frontal and transverse section plans ( $A n$ anterior; Do dorsal; $P R$ post-rostrum; $R$ rostrum) 
Fig. 8. Carapus homei. Schematic view of a frontal section in the sagitta of an adult to illustrate, from the otolith centre to the margin, the opaque central area (zone 1, panel $A$ ) and the banding patterns relative to zones 2 and 3 (panels $B-D)$ (black arrows zone 2 post-metamorphic mark; $O B$, $T B$ opaque and translucent bands, respectively; white arrows zone 3 checks). Panel $A$ : micrograph of the nucleus $(N)$ and larva otolith $(P A)$, until reaching transitional zone 2 . Panel B: micrograph of zone 2 showing larger increments, until reaching the post-metamorphic mark. A discontinuity line is to be noted between the lower, sulcal side and the main part of the otolith. Panel $C$ : banding pattern of zone 3 showing opaque bands $(O B)$ alternating with translucent bands $(T B)$, observed from the post-metamorphic mark to the post-rostrum margin (in panel D)

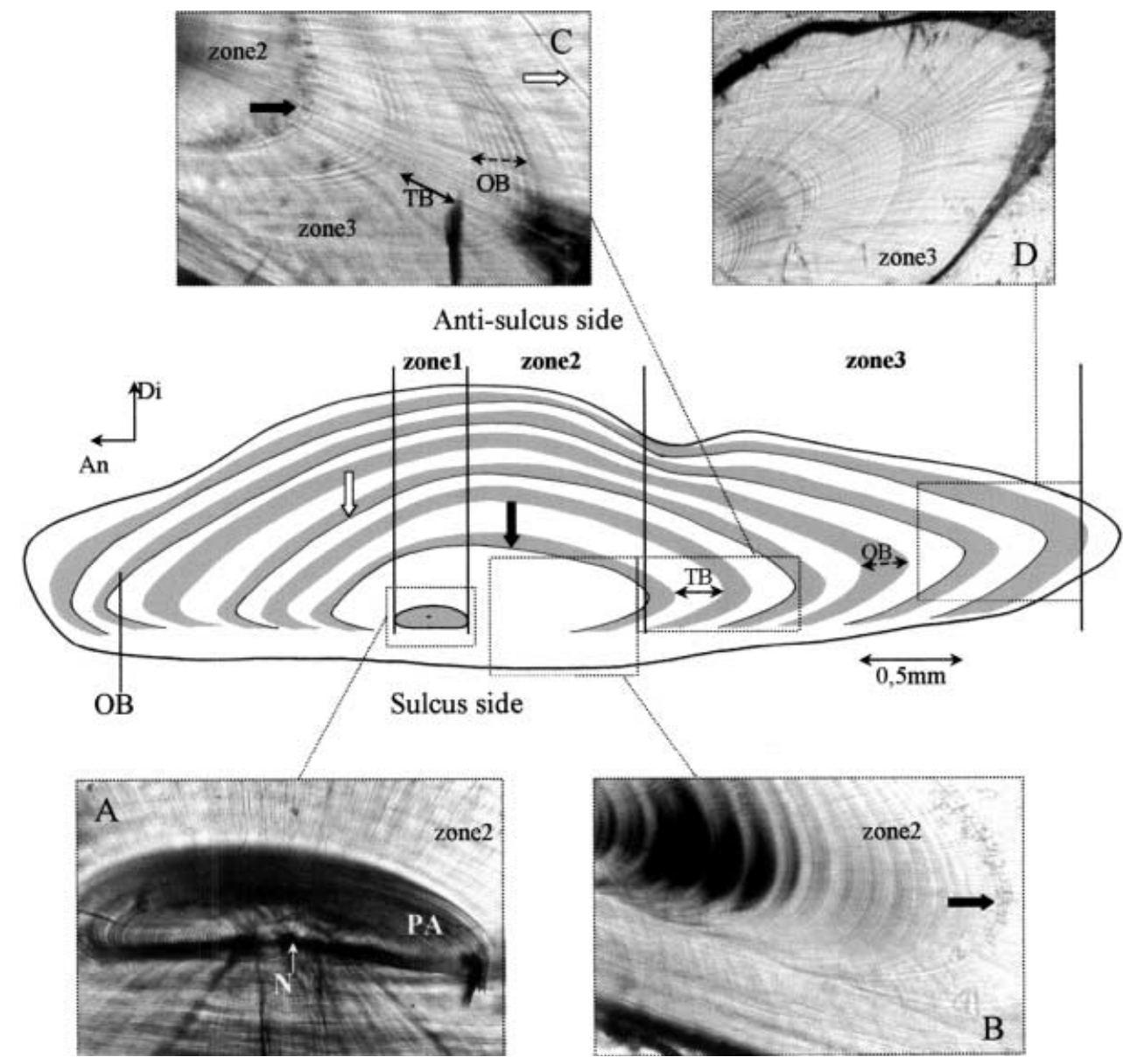

hosts exhibited either zone 1 , or the whole of zone 1 and the beginning of zone 2. Zone 1 thus matched the planktonic-life period, from hatching to immigration and settlement phases (vexillifer larva and early tenuis larva). The smallest juveniles (total length $= \pm 50 \mathrm{~mm}$, in C. boraborensis and $\pm 60 \mathrm{~mm}$ in C. homei) all had sagittae with initiation of zone 3 bands and checks, which was never observed in tenuis sagittae.

\section{Discussion}

Both otolith shape and structure proceed from intrinsic determinants, influenced by life-style and under environmental pressure (Lombarte and Leonart 1993; Campana 1999; Morales-Nin 2000). For a relevant interpretation of otolith-stored information, the main difficulty is to discriminate between the roles played by each of these determinants. Among the intrinsic factors, Gauldie and Nelson (1990) suggested that the sagitta position in the otic capsule could act upon its growth. To our knowledge, previous studies have not dealt with relationships between the sagitta and otic cavity, or reported on eventual constraints imposed by the bony structures during otolith formation. On the other hand, changes in otolith macrostructures produce patterns of growth increments and landmarks. When they are linked to the life-history events of a given species, they offer the necessary base for a first step in interpreting otolith structures (e.g. Sogard 1992; Toole et al. 1993; Molony 1996). For want of direct validation, the relevance of comparing these three Carapini is to establish resemblances or differences between the whole observed structures, in order to relate these patterns to their respective life styles.

Inner ear, otolith growth and tridimensional asymmetry

For most teleostean fish, otolith length is proportional to body length (Campana and Jones 1992), which was not the case in these three carapid species (Fig. 2). However, neurocranium and otolith increased in similar proportions, as previously reported for various leptocephalous larvae (Lecomte-Finiger 1992; Lee and Byun 1996; Wang and Tzeng 2000). At the tenuis stage, the sagitta was limited anteriorly by the prootic wing, on the distal side by the neurocranium walls and ventrally by the prootic and basioccipital. Sagitta growth is however favoured along the antero-posterior axis, on their distal and ventral sides, although the a priori available growing surfaces appear to be the proximal and dorsal faces. This type of developmental process notably departs 
A

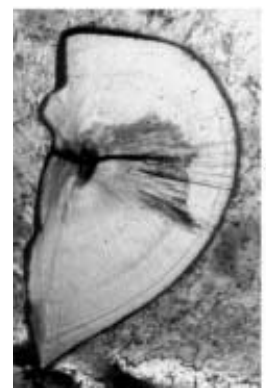

B

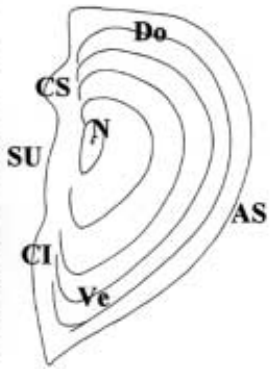

$\mathrm{C}$

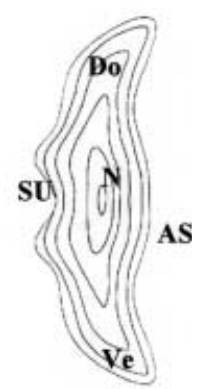

Fig. 9A-C. Carapus boraborensis. A Transverse section micrograph of a sagittal otolith and $\mathbf{B}$ schematic view of this transverse section to compare with a "generalised" otolith model of teleosteans (in C) ( $A S$ anti-sulcus side; $C I$ crista inferior; $C S$ crista superior; Do dorsal; $N$ nucleus; $S U$ sulcus side; $V e$ ventral)

from the model proposed by Gauldie and Nelson (1990), in which physical contact of the otolith against the ventral portion of the cranium restricted otolith growth on the ventral edge.

From the tenuis larva (Fig. 3) to the juvenile (Fig. 4), everything took place as if sagitta growth was responsible for otic cavity development; the prootic, pterotic, intercalarium and parietal were observed to lengthen considerably, while the prootic and basioccipital bent. This led to the sagitta rising, from an approximately antero-ventral to an antero-dorsal orientation, which in turn similarly affected the sphenotic and consequently the recessus utriculi. The pterotic elongation caused an anterior displacement of the arch of the horizontal semicircular canal and an elongation of the pars superior, which thus appeared shorter than in non-otophysi teleosts (Parmentier et al. 2001b). However, if sagitta require space for growth, this suggests that the pressure exerted on the otic cavity could be due to the endolymph. It appears unlikely that brain development could guide otic capsule elongation. Whereas the encephalon filled up most of the space in the tenuis otic cavity, the brain became elongated during ontogenesis and was concentrated forward, with only a thin myelencephalon at the inner ear level (Parmentier et al. 2001b). Furthermore, it was noteworthy that both the inner ear and sagitta shapes in tenuis of these three species were similar to those of Onuxodon fowleri, a Carapidae the adults of which present the least elongation of the otic cavity (Parmentier et al. 2001b). Relationships between the inner ear and sagitta growth in these three Carapini thus suggest an ontogenetic moulding of the otic cavity in its shape and size to allow the development of the statoacoustic organ, rather than a scheme according to which the bony frame physically constrains otolith growth. Other constraints, such as the insertion of the hyomandibula or adductor muscles (Parmentier et al. 1998), could also affect the moulding of the otic cavity.

In generalised otolith models, the sagittal otoliths are described as medially convex and distally concave bodies with a centrally located nucleus (Fig. 9C), or, more
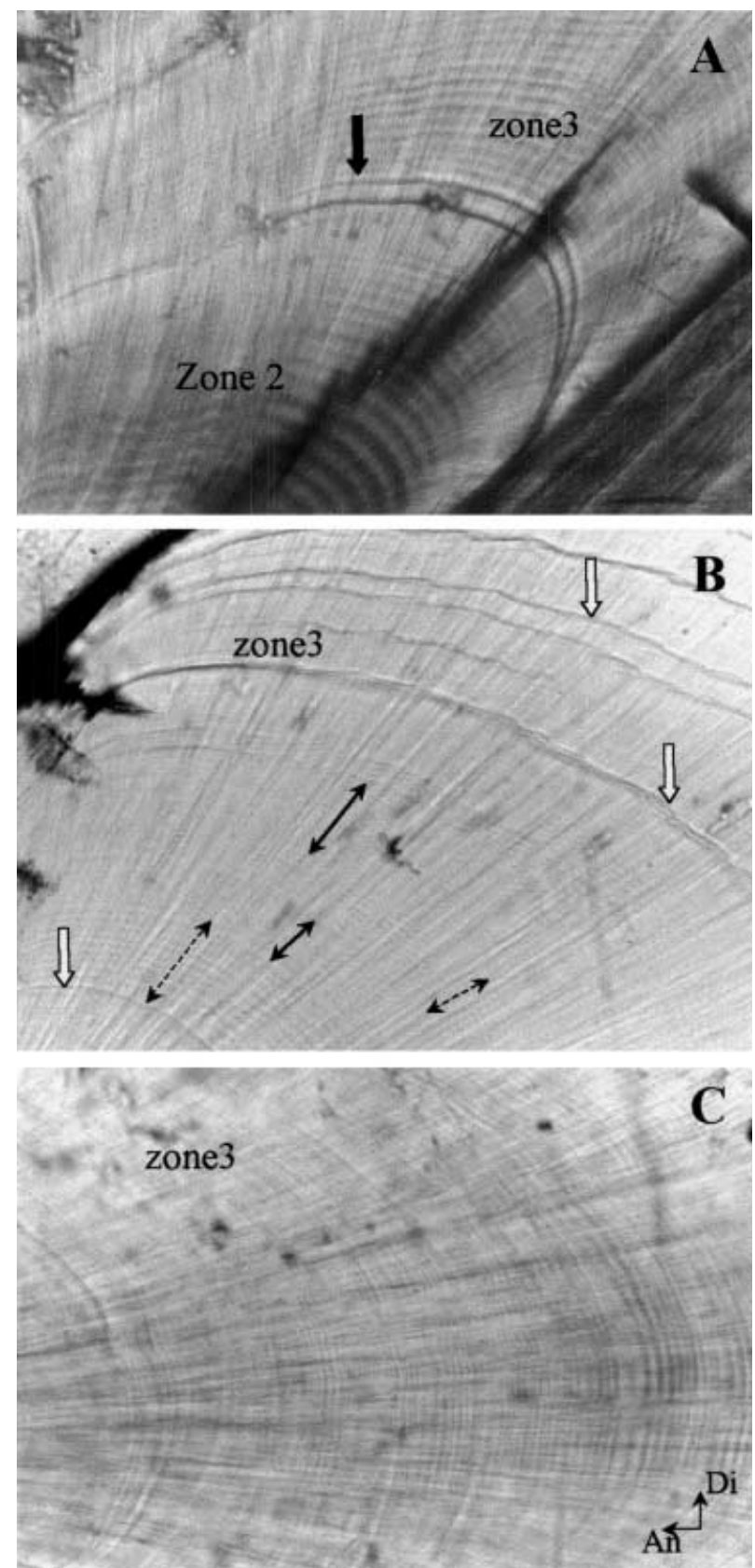

Fig. 10. Carapus boraborensis (A, B), Encheliophis gracilis (C). Illustration of the different zone patterns (black arrow zone 2 postmetamorphic mark; white arrows zone 3 checks; discontinuous double black arrows opaque bands; continuous double black arrows translucent bands; $A n-D i$ antero-distal axes)

often, one positioned closer to the antisulcal side (Dunkelberger et al. 1980; Gauldie and Nelson 1990). Both this shape and nucleus location resulted from the release of soluble $\mathrm{Ca}^{2+}$ on the proximal side, which was in turn precipitated as $\mathrm{CaCO}_{3}$ crystals due to an increasing alkaline gradient, from the sulcal area towards the otolith edge (Mugiya 1974; Gauldie and Nelson 1990). This process has been corroborated by recent studies dealing with the various cellular types of the saccular epithelium (Mayer-Gostan et al. 1997; Takagi 
1997, 2000a,b; Pisam et al. 1998). Depending on the species, variation in distribution within this epithelium of cellular ionic pumps (Mayer-Gostan et al. 1997; Tohse and Mugiya 2001) and of secretory cells (Payan et al. 1998, 1999) led to a solute gradient, the formation of which interfered with otolith bio-calcification by favouring deposition on the proximal side (e.g. in turbot, Scophthalmus maximus, Payan et al. 1999) or on the otolith edge, as in trout (Oncorhynchus mykiss, Payan et al. 1999; Takagi and Takahashi 1999; Takagi 2000b).

The Carapini otoliths strongly departed from the above-mentioned model (Figs. 5, 7, 8, 9). Accretion due to concentric layer deposition was mainly favoured on the distal side and towards the post-rostrum, which resulted in the atypical position of the nucleus and induced tridimensional asymmetry. In deep-sea fishes, the nucleus position was often midway between the sulcus and anti-sulcus sides (Gauldie and Nelson 1990). The endolymphatic sac was shown to present a narrower range of alkaline $\mathrm{pH}$ due to a lower metabolism, which resulted in a distal thickening of the otolith (Gauldie et al. 1991). The specific life style of the three Carapidae, with protracted stays within their hosts (Smith et al. 1981), could also imply a lower metabolism and thus weak $\mathrm{pH}$ variations. For these reasons, studies of the saccular epithelium, with respect to the ionocyte and secretory cell distribution, could provide new tools to further test previously accepted models of otolith formation.

On the other hand, the development of such a shape could also be related to the driving force of hearing. The requirement in hearing capabilities during the development in the hake Merluccius merluccius appears to be different in relation to the feeding behaviour (Lombarte and Popper 1994). In the three Carapini, more than the food uptake, the important development of the saccule and the sagitta could be related to changes in hearing capabilities that are associated with life inside the host. A voluminous sagitta might be linked to a special aptitude to perceive sound in this dark environment (Parmentier et al. 2001b), a condition not encountered in the environment of the tenuis.

\section{Macrostructure interpretation}

Carapini fishes are characterised by five life-history stages: embryo, vexillifer and tenuis larvae, juvenile and adult (Arnold 1956; Trott 1981). This resulted in three main ontogenetic patterns in their otoliths (Fig. 1). Zone 1 covered the pelagic life span, from hatching to the vexillifer larva and the first part of the tenuis stage. While a structural change indicated the limit of zone 1, the tenuis immigrated to the lagoon and settled, in search of hosts. This type of structural change, also mentioned in various coral-reef fish species (e.g. Victor 1982, 1986; Brothers et al. 1983; Wilson and McCormick 1999), could thus be interpreted as a "settlement mark" (Fig. 8A). Zone 2 had the main features of a transition zone formed at the completion of metamorphosis. During this shift of habitat, the tenuis underwent strong anatomical transformations before reaching juvenile status. This was particularly true for the neurocranium and corresponded in the otolith to structural changes, namely the development of low-contrast, wider increments and enhanced tridimensional asymmetry, outlining the adult otolith shape. By ending with a postmetamorphic mark (simple or double, Fig. 8B), zone 2 appeared similar to the transition zone characteristic of species exhibiting strong metamorphic changes (e.g. Campana and Neilson 1985; Lecomte-Finiger 1992; Toole et al. 1993; Lagardère and Troadec 1997). This transition zone corresponded to the second step of the tenuis stage, characterised by a severe reduction in size during metamorphosis (Figs. 1, 2). In C. homei (Fig. 8B), this zone appeared wider than in $C$. boraborensis (Fig. 10A) and E. gracilis. The body elongation was also greater in C. homei tenuis; during settlement, the size ranged between 149 and $183 \mathrm{~mm}$, compared to around $115 \mathrm{~mm}$ in E. gracilis and $90 \mathrm{~mm}$ in C. boraborensis (Parmentier et al. 2001a). As in various leptocephalous larvae (Lee and Byun 1996), the necessary energy supply for metamorphosis could be stored in tenuis tissues. With a longer larva, greater energetic stores could be available to $C$. homei for use during skeleton and otolith formation. Zone 3, deposited from this post-metamorphic mark (Figs. 1, 8C, 10A) to the otolith margin, was shown to correspond to juvenile and adult periods, when the three Carapidae species live inside the holothurians.

Microstructure variations and ecological interpretation

Otolith growth initially depends on endogenous rhythms, with alternating matrix-dominant and calciumcarbonate-dominant deposition, but also on exogenous factors due to environmental conditions, which very likely influence fish metabolism (Campana and Neilson 1985; Morales-Nin 2000). Changes in zone optical characteristics correspond to modifications in the increment width, resulting from variations in photoperiod (Campana 1984; Mugiya 1984), temperature (Degens et al. 1969; Neilson and Geen 1985; Gauldie 1991) and nutritional status (Zhang and Runham 1992; Moksness et al. 1995; Morales-Nin et al. 1995; Molony 1996). On the other hand, except when they are produced by several coalescing microincrements (Jones and Brothers 1987; Tsukamoto and Kajihara 1987), checks correspond to a deficit in calcium carbonate incorporation (Campana 1983; Zhang 1992). They often indicate fish adaptation to a rapid environmental change and could thus provide information on the fish's way of life (Radtke 1987; Morales-Nin 2000), including movements for habitat use (Brothers et al. 1983; Wilson and McfCormick 1999).

The main difference in sagitta microstructure between the three Carapini species involves the zone 3 
patterns of opaque and translucent bands and checks (Figs. 8, 10). The more-or-less regular zone 3 patterns in otoliths of $C$. homei, C. boraborensis and E. gracilis suggest a relationship with aperiodic events. However, $C$. homei and $C$. boraborensis otoliths differed from those of E. gracilis by having a more pronounced banding and prominent checks. These three Carapini were caught in the same lagoon waters, at the same depth and in the same holothurian hosts. In a common environment, abiotic factors, which modulate otolith formation, very likely act in similar ways. Furthermore, strong phylogenetic relationships between species should reduce the influences due to genetic causes. Consequently, it is suggested that differences existing between the otoliths of the parasitic species (E. gracilis) and of the two commensal species (C. homei and $C$. boraborensis) ensue from differences in life style and especially in feeding behaviour. E. gracilis was shown to feed on its host's internal tissues, whereas the two commensal species left their host for prey capture (Van Den Spiegel and Jangoux 1989; Parmentier et al. 2000). For the commensal carapids, this behaviour implies a sudden transition from resting periods in the host to fully active periods in order to chase prey, behavioural changes that trigger deep physiological modifications. Feeding effort results in greater oxygen consumption and energetic inputs, but also in stress due to predator exposure. For Lutjanus kasmira, Morales-Nin and Ralston (1990) suggest a close connection between discontinuity zones and prey capture. Similar results seem to occur in C. homei and C. boraborensis, the otoliths of which showed more prominent checks than those of E. gracilis. However, check formation was also irregular in $C$. homei and $C$. boraborensis. The latter species' ability to feed on other commensal fish captured within a common holothurian host (authors' personal observations) could explain the irregular deposition of checks in their otoliths. On the contrary, the parasitic species was easily distinguished from both commensal species (Fig. 10A, B) on the basis of its more regular patterns in zone 3 (Fig. 10C). A constant energey supply due to parasitism could result in the regular deposition in zone 3 of this species, whereas both the diet and feeding activity were variable in the two commensal species. The latter species had resting and active periods, the duration of which depended on the energy supply provided by ingested prey. For C. bermudensis, Smith et al. (1981) showed a feeding periodicity ranging from 15 to 24 days on average, but able to last up to 60 days. Relationships existing between food intake (or feeding frequency) and width increment variations are well documented (Campana and Neilson 1985; Neilson and Geen 1985; Molony 1996). Given this context and the zone 3 structure, it is suggested that the deposition of checks and opaque bands indicated active metabolism due to periods of feeding activity, whereas deposition of translucent bands reflected fasting periods.

\section{Conclusions}

The primary functions of the sagitta are sound transduction and maintenance of static and dynamic equilibrium (Platt and Popper 1981; Popper and Lu 2000). Biomineral formation is not only under genetic control, but also depends on biological and ecological events. A voluminous sagitta in Carapini appears related to welldeveloped otophysic structures, to the environment and to the life style of carapids (Parmentier et al. 2001b). This study suggests that, with increasing size, the sagitta plays a morphogenetic role in otic cavity development. Furthermore, a close relationship has appeared between the metabolism due to the different life styles of these three Carapini and an unusual sagitta shape, with a rounded distal side, an elongated post-rostrum and strong tridimensional asymmetry. This asymmetry likely results from a differential accretion rate, which determines the shape, but could also depend on food supply. This hypothesis is supported by the otolith structures of these three Carapini. Whilst exposed to the same exogenous factors, they exhibited inter- and intra-specific variations that result in irregular banding patterns, reflecting behavioural differences, in particular, those associated with feeding activity.

Acknowledgements We thank Y. Chancerelle and J. Algret (CRIOBE, Moorea, French Polynesia) for helping to obtain living carapids. Dr. M. Chardon and two anonymous referees provided interesting remarks. This work was supported by grant no. 1.4560.96 from the Belgian "Fonds National de la recherche Scientifique".

\section{References}

Arnold DC (1956) A systematic revision of the fishes of the teleost family Carapidae (Percomorphi, Blennioidea), with description of two new species. Bull Br Mus (Nat Hist) Zool 4:247-307

Brothers EB, Williams DMcB, Sale PF (1983) Length of larval life in twelve families of fishes at "One Tree Lagoon", Great Barrier Reef, Australia. Mar Biol 76:319-324

Campana SE (1983) Feeding periodicity and the production of daily growth increments in otoliths of steelhead trout (Salmo gairdneri) and starry flounder (Platichthys stellatus). Can J Zool 61:1591-1597

Campana SE (1984) Lunar cycles of otoliths growth in the juvenile starry flounder Platichthys stellatus. Mar Biol 80:239-246

Campana SE (1999) Chemistry and composition of fish otoliths: pathways, mechanisms and applications. Mar Ecol Prog Ser 188:263-297

Campana SE, Jones CM (1992) Analysis of otolith microstructure data. Can Spec Publ Fish Aquat Sci 117:73-100

Campana SE, Neilson JD (1985) Microstructure of fish otoliths. Can J Fish Aquat Sci 42:1014-1031

Degens ET, Deuser WG, Haedrich RL (1969) Molecular structure and composition of fish otoliths. Mar Biol 2:105-113

Dufour V, Riclet E, Lo-Yat A (1996) Colonization of reef fishes at Moorea Island, French Polynesia: temporal and spatial variation of the larva flux. NZ J Mar Freshw Res 47:413-422

Dunkelberger DG, Dean JM, Watabe N (1980) The ultrastructure of the otolithic membrane and otolith in the juvenile mummichog, Fundulus heteroclitus. J Morphol 163:367-377

Gauldie RW (1991) The morphology and periodic structures of the otolith of the chinook salmon (Onchorynchus tshawytscha), and 
temperature-dependent variation in otolith microscopic growth increment width. Acta Zool 72:159-179

Gauldie RW, Nelson GDA (1990) Otolith growth in fishes. Comp Biochem Physiol A 97:119-135

Gauldie RW, Coote G, Mulligan KP, West IF, Merrett NR (1991) Otoliths of deep water fishes: structure, chemistry and chemically-coded life histories. Comp Biochem Physiol A 100:1-31

Jangoux M (1974) Sur l'association entre certaines astéries (Echinodermata) et des poissons Carapidae. Rev Zool Afr 88:189196

Jones C, Brothers EB (1987) Validation of the otolith increment aging technique for stripped bass, Morone saxatilis, larvae reared under suboptimal feeding conditions. Fish Bull (Wash DC) $85: 171-178$

Lagardère F, Troadec H (1997) Age estimation in common sole Solea solea larvae: validation of daily increments and evaluation of a pattern recognition technique. Mar Ecol Prog Ser 155:223-237

Lecomte-Finiger R (1992) Growth history and age at recruitment of European glass eels (Anguilla anguilla) as revealed by otolith microstructure. Mar Biol 144:205-210

Lee TW, Byun JS (1996) Microstructural growth in otolith of conger eel (Conger myriaster) leptocephali during the metamorphic stage. Mar Biol 125:259-268

Lombarte A, Leonart J (1993) Otolith size changes related with body growth, habitat depth and temperature. Environ Biol Fishes 37:297-306

Lombarte A, Popper AN (1994) Quantitative analysis of postembryonic hair cell addition in the otolithic endorgans of the inner ear of the European hake, Merluccius merluccius (Gadiformes, Teleostei). J Comp Neurol 345:419-428

Mayer-Gostan N, Kossmann H, Watrin A, Payan P, Bœuf G (1997) Distribution of ionocytes in the saccular epithelium of the inner ear of two teleosts (Oncorhynchus mykiss and Scophthalmus maximus). Cell Tissue Res 289:53-61

Moksness E, Rukan K, Ystanes L, Folkvord A, Johannessen A (1995) Comparison of somatic and otolith growth in North Sea herring (Clupea harengus L.) larvae: evaluation of growth dynamics in mecocosms. In: Secor DH, Dean JM, Campana SE (eds) Recent developments in fish otolith research. University of South Carolina Press, Columbia, pp 119-134

Molony BW (1996) Episodes of starvation are recorded in the otoliths of juvenile Ambassis vachelli (Chandidae), a tropical estuarine fish. Mar Biol 125:439-446

Morales-Nin B (2000) Review of the growth regulation processes of otolith daily increment formation. Fish Res (Amst) 46:53-67

Morales-Nin B, Raltson S (1990) Age and growth of Lutjanus kasmira (Forskål) in Hawaiian waters. J Fish Biol 36:191-203

Morales-Nin B, Guttierrez E, Massutti S (1995) Patterns of primary growth increments in otoliths of Sparus aurata larvae in relation to water temperature and food consumption. Sci Mar 59:57-64

Mugiya Y (1974) Calcium-45 behavior at the level of the otolithic organs of rainbow trout. Nippon Suisan Gakkaishi 40:457-463

Mugiya Y (1984) Diurnal rhythm in otolith formation in the rainbow trout, Salmo gairdeni: seasonal reversal of the rhythm in relation to plasma calcium concentrations. Comp Biochem Physiol A 78:289-293

Neilson JD, Geen GH (1985) Effects of feeding and diet temperature cycles on otolith increment formation in juvenile chinook salmon, Onchorynchus tshawytscha. Fish Bull (Wash DC) 83:91-101

Olney JE, Markle DF (1979) Description and occurrence of vexillifer larvae of Echiodon (Pisces: Carapidae) in the western North Atlantic and notes on other carapid vexillifers. Bull Mar Sci 29:365-379

Padoa E (1947) Note di ittologia mediterranea, Nota V. Forme post-larvali e giovanili di Carapus (sin. Fierasfer). Pubb Staz Zool Napoli 20:111-121

Parmentier E, Chardon M, Poulicek M, Bussers JC, Vandewalle P (1998) Morphology of the buccal apparatus and related structures in four Carapidae. Aust J Zool 46:391-404
Parmentier E, Castillo G, Chardon M, Vandewalle P (2000) Phylogenetic analysis of the pearlfish Carapini (Ophidiiformes, Carapidae). Acta Zool 81:293-306

Parmentier E, Lo-Yat A, Vandewalle P (2001a) Identification of tenuis of four French Polynesian Carapini (Carapidae: Teleostei). Mar Biol 140:633-638. DOI 10.1007/s00227-001-0726-0

Parmentier E, Vandewalle P, Lagardère F (2001b) Morpho-anatomy of the otic region in carapid fishes-eco-morphology study of their otoliths. J Fish Biol 58:1046-1061

Payan P, Borelli G, Bœuf G, Mayer-Gostan N (1998) Relationship between otolith and somatic growth: consequence of starvation on acid-base balance in plasma and endolymph in the rainbow trout Onchorynchus mykiss. Fish Physiol Biochem 19:35-41

Payan P, Edeyer A, de Pontual H, Borelli G, Bœuf G, MayerGostan N (1999) Chemical composition of saccular endolymph and otolith in fish based on the chemistry of the endolymph. Am J Physiol 277:123-131

Pisam M, Payan P, LeMoal C, Edeyer A, Bœuf G, Mayer-Gostan N (1998) Ultrastructural study of the saccular epithelium of the inner ear of two teleosts, Oncorhynchus mykiss and Scophthalmus maximus. Cell Tissue Res 294:261-270

Platt C, Popper AN (1981) Fine structure and function of the ear. In: Tavolga WN, Popper AN, Fay RR (eds) Hearing and sound communication in fishes. Springer, New York Berlin Heidelberg, pp 2-37

Popper AN, Lu Z (2000) Structure-function relationships in fish otolith organs. Fish Res (Amst) 46:15-25

Radtke RL (1987) Age and growth information available from the otoliths of the Hawaiian snapper, Pristipomoides filamentosus. Coral Reefs 6:19-25

Smith CL (1964) Some pearlfishes from Guam, with notes on their ecology. Pac Sci 18:34-40

Smith CL, Tyler JC (1969) Observations on the commensal relationship of the western Atlantic pearlfish, Carapus bermudensis, and holothurians. Copeia 1969:206-208

Smith CL, Tyler JC, Feinberg MN (1981) Population ecology and biology of the pearlfish (Carapus bermudensis) in the lagoon at Bimini, Bahamas. Bull Mar Sci 3:876-902

Sogard SM (1992) Interpretation of otolith microstructure in juvenile winter flounder (Pseudopleuronectes americanus): ontogenetic development, daily increment validation, and somatic growth relationships. Can J Fish Aquat Sci 48:1862-1871

Strasburg DW (1961) Larval carapid fishes from Hawaii, with remarks on the ecology of adults. Copeia 1961:478-480

Takagi Y (1997) Meshwork arrangement of mitochondria-rich, $\mathrm{Na}^{+}, \mathrm{K}^{+}$-ATPase-rich cells in the saccular epithelium of rainbow trout (Onchoryhnchus mykiss) inner ear. Anat Rec 248:483-489

Takagi Y (2000a) Cellular contributions to the otolith formation in teleosts: a review. Otsuchi Mar Sci 25:1-6

Takagi Y (2000b) Ultrastructural immunolocalization of the otolith water-soluble-matrix in the inner ear of rainbow trout justhatched fry. Fish Sci (Tokyo) 66:71-77

Takagi Y, Takahashi A (1999) Characterization of otolith soluble-matrix producing cells in the saccular epithelium of rainbow trout (Onchorryhnchus mykiss) inner ear. Anat Rec 254:322-329

Toole CL, Markle DM, Harris PM (1993) Relationships between otolith microstructure, microchemistry, and early life history events in Dover sole, Microstomus pacificus. Fish Bull (Wash DC) $91: 732-753$

Toshe H, Mugiya Y (2001) Effects of enzyme and anion transport inhibitors on in vitro incorporation of inorganic carbon and calcium into endolymph and otoliths in salmon Oncorhynchus masou. Comp Biochem Physiol A 128:177-184

Trott LB (1970) Contribution of the biology of carapid fishes (Paracanthopterygian: Gadiformes). Univ Calif Publ Zool 89:1-41

Trott LB (1981) A general review of the pearlfishes (Pisces, Carapidae). Bull Mar Sci 31:623-629

Tsukamoto K, Kajihara T (1987) Age determination of ayu with otolith. Nippon Suisan Gakkaishi 53:1985-1997 
Van Den Spiegel D, Jangoux M (1989) La symbiose entre poissons Carapidae et Holoturies autour de l'île de Laing (Mer de Bismarck, Papouasie Nouvelle Guinée). Indo-Mal Zool 6:223228

Victor BC (1982) Daily otolith increments and recruitment in two coral-reef wrasses, Thalassoma bifasciatum and Halichores bivitatus. Mar Biol 71:203-208

Victor BC (1986) Delayed metamorphosis with reduced larval growth in a coral reef fish (Thalassoma bifasciatum). Can J Fish Aquat Sci 43:1208-1213
Wang CH, Tzeng WN (2000) The timing of metamorphosis and growth rates of American and European eel leptocephali: a mechanism of larval segregative migration. Fish Res (Amst) 46:191-205

Wilson DT, McCornick MI (1999) Microstructure of settlementmarks in the otoliths of tropical reef fishes. Mar Biol 134:29-41

Zhang Z (1992) Ultrastructure of otolith increments and checks in the teleost fish Oreochromis niloticus. J Morphol 211:213-220

Zhang Z, Runham NW (1992) Otolith microstructure pattern in Oreochromis niloticus (L.). J Fish Biol 40:325-332 